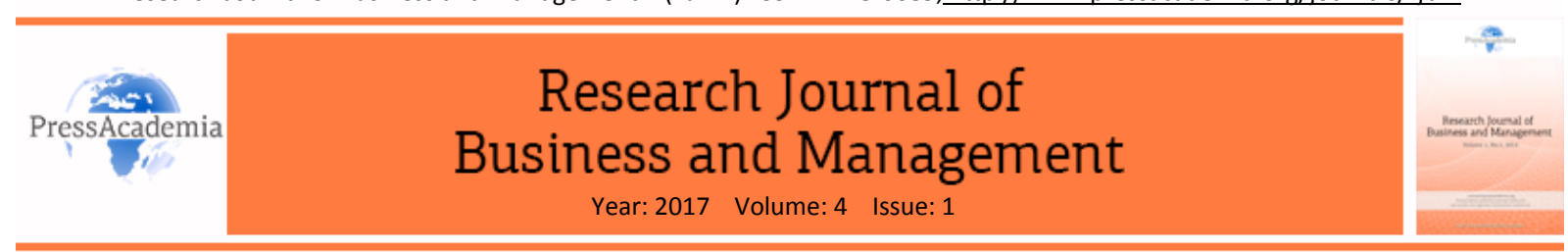

\title{
DETERMINATION OF THE RELATIONSHIP BETWEEN MATHEMATICS LITERACY, MATHEMATICS CONTENT KNOWLEDGE AND SCIENCE LITERACY ACCORDING TO PISA 2012
}

\author{
DOI: 10.17261/Pressacademia.2017.373 \\ RJBM-V.4-ISS.1-2017(8)-p.84-89
}

\author{
Dilber Polat ${ }^{1}$, Yasemin Godek ${ }^{2}$, Volkan Hasan Kaya ${ }^{3}$ \\ ${ }^{1}$ Ahi Evran Üniversitesi, Matematik ve Fen Bilimleri Eğitimi Bölümü, Kirsehir, Turkey. d.polat218@gmail.com \\ ${ }^{2}$ Türkiye Cumhuriyeti Gençlik ve Spor Bakanlığı, Ankara, Turkey. yasemin.godek@gsb.gov.tr \\ ${ }^{3}$ Gazi Üniversitesi, Eğitim Bilimleri Enstitüsü, Ankara, Turkey. volk.has.an@gmail.com
}

To cite this document

Polat, D. and Y. Godek and V.H. Kaya, (2017). Determination of the relationship between mathematics literacy, mathematics content knowledge and science literacy according to PISA 2012. Research Journal of Business and Management (RJBM), V.4, Iss.1, p.84-89. Permemant link to this document: $\underline{\text { http://doi.org/10.17261/Pressacademia.2017.373 }}$

Copyright: Published by PressAcademia and limited licenced re-use rights only.

\section{ABSTRACT}

Purpose- In the PISA (Program for International Student Assessment), science and mathematics literacy are emphasized. PISA data are being benefited in directing education policies. In this study, it was aimed to determine the relationship between Mathematics Literacy, Mathematics Content Knowledge and Science Literacy of 15 years old students in Turkey by using PISA 2012 data. Moreover, it was aimed to reveal whether there is any relationship between the time spent on science and mathematics outside the school and students' Science Literacy.

Methodology- This study is a descriptive research. As a research instrument, the researchers used the results of cognitive tests utilised by PISA in 2012 to assess students' science and mathematics literacy skills. The data were obtained from the official website of PISA. In this study, parametric tests were used in evaluating the quantitative data. An ANOVA test and the correlation were used.

Findings- The results show that there is a positive and meaningful relationship between Mathematic Literacy, Mathematic Content Knowledge and Science Literacy. Furthermore, it was found that there is a positive and meaningful relationship between the time spent on science and mathematics outside the school and students' Science Literacy.

Conclusion- According to the results of this study, it might be said that Mathematics literacy, Mathematics Content Knowledge and the time devoted by students to Mathematics and Science outside of the school increase, the Science Literacy increases. In addition, it was revealed that the students who have a good understanding of Mathematics are more positive in Science Literacy. Therefore, the mathematical concepts related to the science should be included in the science curriculum after being taught in the mathematics course, this will contribute to science literacy of the students.
\end{abstract}

Keywords: Science, science literacy, PISA 2012, mathematic literacy, mathematic content knowledge JEL Codes: 120,121

\section{INTRODUCTION}

In today's information society, it is the crucial indicator to determine what students know, how much they know, how much they have the skills, and what are the deficiencies in their knowledge and skills, in revealing the current situation of the education system (Özer \& Anıl, 2011). This situation is also valid for Science which is one of the special areas of education. In developing Science Curriculum, the curriculum developers should develop new goals and objectives as individuals reach to the desired levels in line with the vision the curriculum developers have developed (Büyükalan Filiz \& Kaya, 2013). In this regard, it is possible to train individuals who can adapt to different conditions and think different, flexible and original, which is the most important objective of education (Özsoy-Güneş \& et al., 2013). Therefore, the importance of developing new generation as literate, as well as scientifically literate, is increasing day by day, to achieve and maintain the level of 
contemporary civilizations in the future, to create and develop technologies to meet the demands of the society, and to create the infrastructure of the future technologies by foreseeing the demands of the future generations (Kaya \& Doğan, 2016).

The changing needs of the society require some changes in the competencies of the students who graduate from educational institutions. In this context, Turkish Ministry of National Education has revised the "Science and Technology Curriculum" which put into practice in the 2004-2005 academic year. The revised curriculum is now called as "Science Curriculum" and is being gradually started to apply from the 5th grades in the 2013-2014 academic year (Kaya \& Taşdemir, 2014). The vision of both the Science and Technology Curriculum and Science Curriculum is defined as "to educate all students as scientifically literate individuals". Through scientific literacy, it was aimed to cultivate curious and sensitive people in their own veil of the nature (Kaya \& Kazancı, 2009).

The most important element of being an information society is education, and the necessity of the concept of literacy in education programs has been revealed through the research. In today's program development studies, the concept of literacy is more detailed. Even though scientific literacy is widely used to achieve desired outcomes in science education, it seems that there is not yet any consensus on its definition (DeBoer, 2000). Researchers are trying to draw some boundaries on what this concept should be understood and how it can be assessed. In terms of its scope, the concept of literacy consists of Science Literacy and Mathematical Literacy. While Science Literacy is used to describe the questions of the possessed science knowledge, acquire new knowledge, explain the scientific facts, makes inferences based on the scientific evidences and, as a thoughtful citizen, deals with scientific issues and scientific ideas; Mathematical Literacy involves the ability to recognize and formulate mathematical problems in a variety of situations using mathematics more broadly and functionally (PISA 2007).

Even though reading skills, Science and Mathematics Literacy are independently evaluated, the research show that there is interdisciplinary links between them (Başkan Takaoğlu, 2015; Güneyli et al., 2010; Kanatlı \& Çekici, 2013; Özer \& Anıl, 2011; Wang, 2005). This link allows students to gain the abilities to think and evaluate and life-orientation benefits through integrating different disciplines (Kanatlı \& Çekici, 2013). This is due to the interdisciplinary relations being related to the integration of knowledge and skills specific to different disciplines, the establishment of links and the formation of comprehensive learning areas (Güneyli, et al., 2010). Especially this situation is frequently encountered in science. One of the reasons for this is the fact that learning through making connection between different disciplines contributes positively to link science, technology and society (Başkan Takaoğlu, 2015). Another reason is that science and mathematics are the fields in which the applications of knowledge that support each other and outcomes of learning are clearly visible (Saracaloğlu, et al., 2006). In fact, John Perry, a professor of mathematics, remarked that in 1901 there was a need for more correlation between mathematics and science teaching (Kullman, 1966). The relationship between science and mathematics is used in different ways by science and mathematics education communities (Davison, et al., 1995). One of the examples of this situation is that the applications of Science-Technology-Engineering-Mathematics (STEM) which started to be used in recent years. Two of these four concepts are science and mathematics, and the relationship between these concepts is tried to be conveyed to the curriculum. From this respect, the curriculum developers should be supported through researches carried out both at national and international levels.

The International Student Assessment Program (PISA) provides us with noteworthy information on whether students are at the expected level and whether they have achieved the desired level compared to other countries. PISA is administered by the Organization for Economic Cooperation and Development (OECD) to students in the age group of 15. In PISA tests, the data are collected concerning students' Mathematical Literacy, Science Literacy and Reading Skills as well as their motivation, learning styles, school settings, families, and their opinions about themselves. PISA, which has been regularly and consistently applied every three years since 2000, is carried out in the form of cyclical weighting of one of the areas of mathematics, science and reading skills (MEB, 2015). In PISA; the emphasis is placed on the importance of the concepts of Science and Mathematical Literacy, and life-long learning, and it is aimed to use the data related to learning outcomes in directing education policies (MEB, 2010a; MEB, 2010b). At PISA 2012, paper-pencil assessment was used and each student was taken to a two-hour evaluation that included multiple-choice tests, closed-ended questions, structured open-ended questions and short-answer questions (NCES Handbook of Survey Methods, 2014).

In Turkey, researchers aim to develop the science curriculum in the direction of the analysis of the data obtained from both national and international assessment programs. In order to contribute this, the aim of this study was to determine the relationship between Mathematics Literacy and Mathematics Content Knowledge and Science Literacy of Turkish students according to PISA 2012 data. Accordingly, it will be determined whether there is any meaningful relationship between Mathematics Literacy and Mathematics Content Knowledge and Science Literacy. Furthermore, it will also be attempted to show whether the time students devote to science and mathematics outside of the school is an effect on Science Literacy. Therefore, in the following parts of this study, the information about the methodology will be given, then the findings will be presented, and finally, it will be concluded by some suggestions for science curriculum developers and science teachers. 


\section{METHODOLOGY}

The model of this research is a descriptive study. The main purpose of the descriptive analysis is to provide the reader with the ability to summarize and interpret the findings obtained with the aid of the obtained data (Yıldırım \& Şimşek, 2003). At PISA 2012, cognitive tests were used to measure skills in science and mathematics literacy. In this study, the data collected through student surveys, science and mathematics literacy cognitive tests utilized in PISA 2012 were benefited from.

The data have been obtained via the internet from the official PISA site (http://www.pisa.oecd.org). SPSS 15 program was used to analyze the data. In the analysis, relationships between predictor variables (Mathematical Literacy and Mathematical Content Knowledge) and dependent variable (Science Literacy) have been tested. In this way, interdisciplinary connections can be revealed. In this study, parametric tests were applied in evaluating the data obtained from the analysis of quantitative data. An ANOVA test was used to test whether three or more averages were equal. Correlation analysis was also performed.

\section{FINDINGS}

In this section, through SPSS analysis, the answer was sought to research question. The results of the analysis are displayed in the tables according to whether they are statistically significant or not. Table 1 shows the correlation between Science Literacy (SL) and Mathematical Literacy (ML).

Table 1: The correlation between Science Literacy (SL) and Mathematical Literacy (ML)

\begin{tabular}{cccc}
\hline & & SL & ML \\
SL & $r$ & 1 & \\
& $\mathrm{p}$ & & \\
& $\mathrm{N}$ & 4848 & 1 \\
$\mathrm{ML}$ & $\mathrm{r}$ &, $914\left(^{* *}\right)$ & \\
& $\mathrm{p}$ &, 000 & 4848 \\
\hline$* * \mathrm{p}<0.01$ & $\mathrm{~N}$ & 4848 &
\end{tabular}

As can be seen in the Table 1., there seems to be a positive and meaningful relationship between Science Literacy and Mathematical Literacy at a high level $\left(r=0.914, r^{2}=0,84 p<.01\right)$. Accordingly, it can be said that as Mathematical literacy increases, Science Literacy increases. In other words, any kind of work or activity to increase Mathematical Literacy of the students will contribute to Science Literacy of the students. It can also be said that approximately $84 \%$ of the variance observed in Science Literacy depends on Mathematical Literacy.

Table 2 shows the correlation between Science Literacy and the topics related to mathematics content knowledge.

Table 2: The correlation between Science Literacy and the topics related to Mathematics Content Knowledge

\begin{tabular}{|c|c|c|c|c|c|c|}
\hline & & SL & $\begin{array}{l}\text { Divisor - } \\
\text { common divisor } \\
\text { (BK) }\end{array}$ & $\begin{array}{c}\text { Rational } \\
\text { Numbers } \\
\text { (RK) }\end{array}$ & $\begin{array}{l}\text { Polygons } \\
\text { (PK) }\end{array}$ & $\begin{array}{l}\text { Arithmetic } \\
\text { mean } \\
\text { (AO) }\end{array}$ \\
\hline & $\mathrm{R}$ & 1 &, $313(* *)$ &, $271(* *)$ &, $186(* *)$ &, $313(* *)$ \\
\hline \multirow[t]{2}{*}{ SL } & $P$ & & ,000 & ,000 & ,000 & ,000 \\
\hline & $\mathrm{N}$ & 4848 & 4848 & 4848 & 4848 & 4848 \\
\hline
\end{tabular}

** $p<0.01$

There appears to be a positive and positive relationship between Science Literacy and Mathematics Content Knowledge at moderate or low levels $\left(r_{\mathrm{BK}}=0.313, \mathrm{r}_{\mathrm{BK}}^{2}=0.10 ; \mathrm{r}_{\mathrm{RK}}=0.271, \mathrm{r}_{\mathrm{RK}}^{2}=0.04 ; \mathrm{r}_{\mathrm{PK}}=0.186, \mathrm{r}_{\mathrm{PK}}^{2}=0.04 ; \mathrm{r}_{\mathrm{AO}}=0.313, \mathrm{r}_{\mathrm{AO}}^{2}=0.10 \mathrm{p}<.01\right)$. It can be stated that approximately $10 \%$ of the variance observed in Science Literacy depends on the concepts of "Divisor" and "Arithmetic Mean", and $4 \%$ on the concepts of "Rational Number" and "Polygons". Accordingly, it can be said that as Mathematics Content Knowledge increases, Science Literacy increases. In other words, any work or activity that enhances the Mathematics Content Knowledge will contribute to the Science Literacy of the students. 
Table 3 shows the results of ANOVA according to Science Literacy and Mathematics Content Knowledge.

Table 3: The results of ANOVA according to Science Literacy and Mathematics Content Knowledge

\begin{tabular}{|c|c|c|c|c|c|c|c|c|}
\hline & $\begin{array}{l}\text { Source of } \\
\text { variance }\end{array}$ & $\begin{array}{l}\text { Sum of } \\
\text { squares }\end{array}$ & sd & $\begin{array}{l}\text { Mean } \\
\text { square }\end{array}$ & $\mathbf{F}$ & $\mathbf{P}$ & $\begin{array}{l}\text { Significant } \\
\text { difference }\end{array}$ & $\eta 2$ \\
\hline & $\begin{array}{l}\text { Between } \\
\text { groups }\end{array}$ & 3240666,1 & 5 & 648133,2 & & & & \\
\hline \multirow{3}{*}{$\begin{array}{l}\text { Divisor - } \\
\text { common } \\
\text { divisor }\end{array}$} & With-in group & 25012990,7 & 4842 & 5165,8 & 125,5 & .000 & $A-B, A-C, A-D, A-E$ & 0,12 \\
\hline & Total & 28253656,8 & & & & & & \\
\hline & $\begin{array}{l}\text { Between } \\
\text { groups }\end{array}$ & 2426908,6 & 5 & 485381,8 & & & & \\
\hline \multirow[t]{3}{*}{$\begin{array}{l}\text { Rational } \\
\text { Numbers }\end{array}$} & With-in group & 25826748,3 & 4842 & 5333,9 & 91,0 & .000 & $\mathrm{~A}-\mathrm{B}, \mathrm{A}-\mathrm{C}, \mathrm{A}-\mathrm{D}, \mathrm{A}-\mathrm{E}$ & 0,09 \\
\hline & Total & 28253656,9 & & & & & & \\
\hline & $\begin{array}{l}\text { Between } \\
\text { groups }\end{array}$ & 1591377,1 & 5 & 318275,4 & & & & \\
\hline \multirow[t]{3}{*}{ Polygons } & With-in group & 26662279,8 & 4842 & 5506,5 & 57,8 & .000 & $A-B, A-C, A-D, A-E$ & 0,06 \\
\hline & Total & 28253656,9 & & & & & & \\
\hline & $\begin{array}{c}\text { Between } \\
\text { groups }\end{array}$ & 3276360,1 & 5 & 655272,0 & & & & \\
\hline \multirow[t]{2}{*}{$\begin{array}{l}\text { Arithmetic } \\
\text { mean }\end{array}$} & With-in group & 24977296,8 & 4842 & 5158,5 & 127,1 & .000 & $A-B, A-C, A-D, A-E$ & 0,12 \\
\hline & Total & 28253656,9 & & & & & & \\
\hline
\end{tabular}

The results of the analysis show that there is a meaningful difference in terms of Science Literacy averages and the topics of Mathematics Content Knowledge of Turkish students, $F_{\text {divisors }}(5,4842)=125,5 ; F_{\text {Rational Numbers }}(5,4842)=91,0 ; F_{\text {Poligons }}(5,4842)$ $=57,8 ; F_{\text {Arithmetic mean }}(5,4842)=127,1 ; p<0.01$. According to the results of the Scheffe test, Science Literacy of the students who understand the concept of "divisor" ( $A)(X=497,90)$ were more positive than those who heard this concept frequently $(X=447,54)$ (C) those who heard once or twice $(X=409.49)(D)$ and those who had never heard $(X=413,97)$. Science Literacy of the students who understand the concept of "rational numbers" $(X=489,34)$, were more positive than those who heard this concept frequently $(X=445,47)$, those who heard it several times $(X=421,36)$, those who heard once or twice $(X=395,59)$ and those who never heard $(X=423,64)$. Science Literacy of the students who understand the concept of "Polygons" $(X=507,59)$ more positive than those who heard this concept frequently $(X=458,20)$, those who hear several times $(X=453,85)$, those who hear once or twice $(X=449,57)$ and those who never heard $(X=450,40)$.

Science literacy of the students who understand the concept of "arithmetic mean" $(X=495,60)$ more positive than those who heard this concept frequently $(X=442,84)$, those who heard several times $(X=430,34)$, those who heard once or twice $(X=417,46)$ and those who had never heard $(X=405,14)$.

Table 4 shows the correlation between Science Literacy and the time devoted to Mathematics Outside of the School Time (MOST) and Science Outside of the School Time (SOST). 
Table 4: The Correlation between SL and the MOST and SOST

\begin{tabular}{ccccc}
\hline & & SL & MOST & SOST \\
& $r$ & 1 &, $109\left(^{* *}\right)$ &, $102\left(^{* *}\right)$ \\
SL & $\mathrm{p}$ & &, 000 &, 000 \\
& $\mathrm{~N}$ & 4848 & 4848 & 4848 \\
\hline
\end{tabular}

** $p<0.01$

There appears to be a positive and meaningful relationship between the Science Literacy and the time devoted to Mathematics Outside of the School Time (MOST) and Science Outside of the School Time (SOST) at low level $\left(r_{\text {MOST }}=0.109\right.$, $\left.r_{\text {MOST }}^{2}=0,01 ; r_{\text {SOST }}=0.102, r_{\text {SOST }}^{2}=0,01, p<.01\right)$. Accordingly, it can be said that as the time devoted to Mathematics and Science Outside of the School Time increases, the Science Literacy increases. When Figure 1 is examined, $41 \%$ of Turkish students who participated to PISA 2012 test stated that they do not devote any time to mathematics and $46 \%$ to science. Therefore, it might be said that not devoting any extra time to mathematics and science outside of the school time might affects students' science literacy negatively.

Figure 1: Time devoted to Mathematics Outside of the School Time (MOST) and Science Outside of the School Time (SOST)

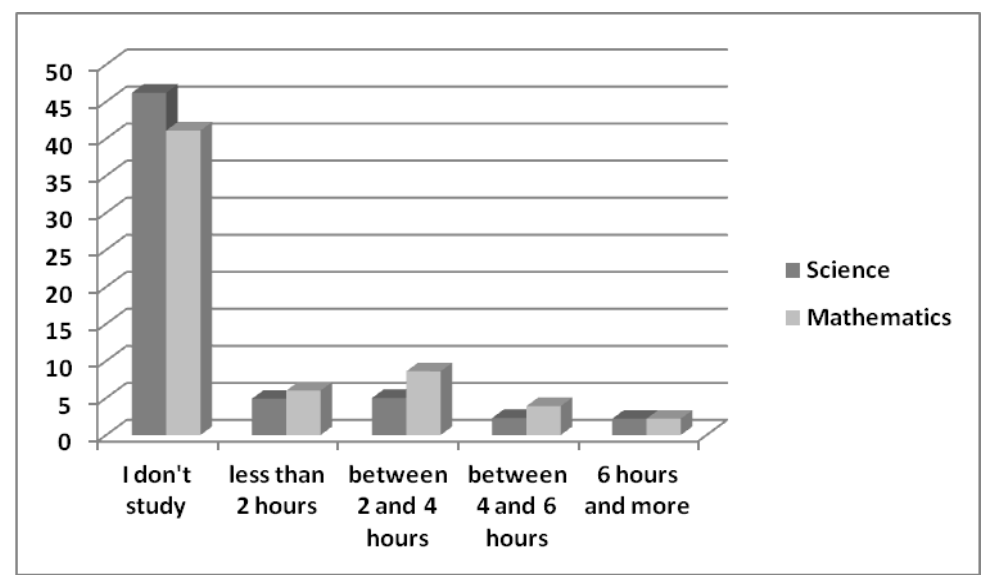

\section{CONCLUSION and SUGGESTIONS}

The findings of this study presents that there seems to be a positive and meaningful relationship between Mathematical Literacy, Mathematics Content Knowledge and Science Literacy. It was also found that there seems a positive and significant relationship between Science Literacy and the time devoted by students to Mathematics and Science outside of the school. According to this, it might be said that Mathematics literacy, Mathematics Content Knowledge and the time devoted by students to Mathematics and Science outside of the school increase, the Sciences Literacy increases. In addition, it was determined that the students who have a good understanding of Mathematics are more positive in Science Literacy. For this reason, while science curricula are being planned it should be considered that, the mathematical concepts related to the science should be included in the science curriculum after being taught in the mathematics course, this will contribute to science literacy of the students. For example, in order to understand the concepts such as "speed" and "density" in a more qualified way, mathematical concepts related to these concepts must be learned in advance. In addition, science teachers should adopt interdisciplinary approach and should spare some time to these mathematical concepts in their lessons (Kaya, et al., 2012). Science Curriculum developers should take into consideration the effect of the disciplinary concepts on teaching of science topics.

Furthermore, students should be encouraged to participate in science and mathematics activities outside the school. Especially in this context, science teachers should be role models to the students and parents in visiting various non-school environments (Kaya, et al., 2014). 


\section{REFERENCES}

Başkan Takaoğlu, Z. (2015). Matematiksel Modelleme Kullanılan Fizik Derslerinin Öğretmen Adaylarının İlgi, Günlük Hayat ve Diğer Derslerle İlişkilendirmelerine Etkisi, YYÜ Eğitim Fakültesi Dergisi,Cilt:XII, Sayı:I, 223-263 http://efdergi.yyu.edu.tr.

Büyükalan Filiz, S. \& Kaya, V. H. (2013). Examine the Relationship Between the Curriculum of Science and Technology Course in Elementary Education and the Curriculum of Undergraduate and Graduate Programs of Science Teacher Education in Terms of Philosophy, Goal and Content., Journal of Turkish Educational Science, 11 (2), 185-208.

Davison, D., Miller, K, W. \& Metheny, D. L. (1995). What Does Integration of Science and Mathematics Really Mean? School Science and Mathematics, Volume 95(5), 226-230.

Deboer, G. E. (2000). Scientific Literacy: Another Look at Its Historical and Contemporary Meanings and Its Relationship to Science Education Reform, Journal of Research in Science Teaching, 37(6), 582-601.

Güneyli, A., Özder, H., Konedralı, G. ve Arsan, N. (2010). İlköğretim Öğrencilerinin Türkçe İle Diğer Ders Başarıları Arasındaki i̇lişki, Mediterranean Journal of Educational Research, 3(7), 60-72.

Kanatlı, F. \& Çekici, Y. E. (2013). Türkçe Öğretiminde Disiplinler Arası Olanaklar, Mersin Üniversitesi Eğitim Fakültesi Dergisi, Cilt 9, Sayı 2, ss.223-234.

Kaya, V. H. \& Dogan, A., (2016). According to PISA 2012, The Determination and Comparison of the Student Factors Affecting the Science Literacy of the Students in Turkey, International Conference on Quality in Higher Education Proceeding Book, Sakarya, Turkey.

Kaya, V. H. \& Kazancı, E. (2009), Ekolojik Okuryazarlık, Bilim ve Teknik Dergisi- Yıldız Takımı Eki, Sayı 11.

Kaya, V. H., Godek Altuk, Y., \& Bahceci, D, (2012), Elementary School Students' Views and Images Concerning Science Teachers, Procedia Social and Behavioral Sciences, Volume 47, Pages 433-438.

Kaya, V. H., Polat, D. \& Kaya, E. (2014). Gözlemevi Ziyaretinin Ortaokul Öğrencilerinin Astronomi Konusundaki Algılarına Etkisinin İncelenmesi (Ankara İli Örneği), XI. Ulusal Fen Bilimleri ve Matematik Eğitimi Kongresi, Çukurova Üniversitesi, Adana.

Kaya, V. H. \& Taşdemir, A. (2014). Gökbilimci (Astronom) ve Gözlemevine Yönelik Algılar, XI. Ulusal Fen Bilimleri ve Matematik Eğitimi Kongresi, Çukurova Üniversitesi, Adana.

Kullman, D. E. (1966). Correlation of Mathematics and Science Teaching, School Science and Mathematics, Vol. 66, Issue 7.

Milli Eğitim Bakanlığı. (2007). PISA 2006 Uluslararası Öğrenci Değerlendirme Programı Ulusal Ön Rapor, Eğitimi Araştırma ve Geliştirme Dairesi Başkanlığı, Ankara.

Milli Eğitim Bakanlığı. (2010a). PISA 2009 Projesi Ulusal Ön Raporu, Eğitimi Araştırma ve Geliştirme Dairesi Başkanlığı, Ankara.

Milli Eğitim Bakanlığı. (2010b). PISA 2012 Türkiye, Eğitimi Araştırma ve Geliştirme Dairesi Başkanlığı, Ankara.

Milli Eğitim Bakanlığı (2015). PISA 2012 Araştırması Ulusal Nihai Rapor, Ölçme, Değerlendirme ve Sınav Hizmetleri Genel Müdürlüğü, Ankara.

NCES Handbook of Survey Methods. (2014). Program for International Student Assessment (PISA), Erişim Adresi: http://nces.ed.gov/Surveys/PISA/.

Özer, Y. \& Anıl, D. (2011). Öğrencilerin Fen ve Matematik Başarılarını Etkileyen Faktörlerin Yapısal Eşitlik Modeli İle İncelenmesi, Hacettepe Üniversitesi Eğitim Fakültesi Dergisi, 41, 313-324.

Özsoy-Güneş, Z., Çıngıl-Barış, Ç. \& Kırbaşlar, F. G. (2013). Fen Bilgisi Öğretmen Adaylarının Matematik Okuryazarlığı Öz-Yeterlik Düzeyleri İle Eleştirel Düşünme Eğilimleri Arasındaki İlişkilerin İncelenmesi, Hasan Ali Yücel Eğitim Fakültesi Dergisi, Sayı 19, 47-64.

Saracaloğlu, A. S., Özyılmaz Akamca, G. \& Yeşildere, S. (2006). Illköğretimde Proje Tabanlı Öğrenmenin Yeri, Türk Eğitim Bilimleri Dergisi, Cilt 4, Sayı 3.

Wang, J. (2005). Relationship Between Mathematics and Science Achievement at the 8th Grade, Int Online Journal of Science Math Education, vol 5, 1-17.

Yıldırım, A. \& Şimşek, H. (2003). Sosyal Bilimlerde Nitel Araştırma Yöntemleri. Ankara: Seçkin Yayınları. 